УДК 343.13

DOI https://doi.org/10.32837/apdp.v0i83.138

Т. Г. Фоміна

\title{
ПРЕВЕНТИВНЕ ЗАТРИМАННЯ: ЗАПОБІЖНИЙ АБО «ПОЗАПРОЦЕСУАЛЬНИЙ» ЗАХІД?
}

Постановка проблеми. В умовах здійснення воєнних дій на Сході України в 2014 р. було прийнято рішення про проведення антитерористичної операції. 3 метою унормування порядку здійснення кримінального судочинства в таких особливих умовах до законодавства було внесено низку змін та доповнень. Зокрема, КПК України доповнено Розділом IX-1 «Особливий режим досудового розслідування в умовах воєнного, надзвичайного стану або у районі проведення антитерористичної операції». Значну увагу законодавцем було приділено й регламентації порядку затримання осіб, що підозрюються у вчиненні терористичної діяльності.

Превентивне затримання «з'явилось» у національному законодавстві з 12.08.2014 р. у зв’язку з доповненням Закону України «Про боротьбу з тероризмом» статтею 15-1 «Особливості превентивного затримання у районі проведення антитерористичної операції осіб, причетних до терористичної діяльності» [1]. Поява цього виду затримання спричинила серед представників наукової спільноти, правозахисних організацій та практиків суперечки щодо доцільності його існування. Відтак, є необхідність вивчення цього питання та пошуку шляхів вирішення проблем, пов'язаних із регламентацією порядку превентивного затримання.

Аналіз останніх досліджень і публікацій. Питання здійснення досудового розслідування в особливому режимі вивчали такі процесуалісти, як О.В. Капліна, М. Лисенков, I.В. Рогатюк, М.С. Туркач, 0.0. Юхно та інші. Враховуючи напрацювання науковців, які вже звертали увагу на значну кількість нормативних колізій та прогалин правової регламентації стосовно порядку здійснення розслідування злочинів, учинених на території проведення антитерористичної операції, автор вважає за необхідне свою увагу приділити детальному вивченню порядку здійснення превентивного затримання.

Метою статті є, по-перше, визначення сучасних проблем регламентації порядку превентивного затримання; по-друге, окреслення проблемних моментів щодо визначення строків превентивного затримання та суб'єктів його здійснення; по-третє, з'ясування відмінностей між превентивним затриманням та затриманням у порядку ст. 208 КПК України, а також триманням під вартою; по-четверте, висловлення власного погляду щодо можливого вдосконалення законодавства в частині регламентації порядку превентивного затримання.

Виклад основного матеріалу дослідження. Починаючи розгляд заявленої проблематики, перш за все, слід звернути увагу на той факт, що превентивне затримання передбачене лише Законом України «Про боротьбу з тероризмом» (ч. 3 ст. 14, ст. 15-1). Також порядок цього виду затримання регламентовано на підзаконному piвні, а саме Інструкцією про порядок превентивного затримання у районі проведення антитерористичної операції осіб, причетних до терористичної діяльності, та 
особливого режиму досудового розслідування в умовах воєнного, надзвичайного стану або у районі проведення антитерористичної операції, затвердженої спільним наказом МВС, ГП, СБУ України від 26.08.2014 р. (далі - Інструкція про порядок превентивного затримання) [2].

У КПК України про превентивне затримання не йдеться. Втім, слід врахувати, що згідно ч. 1 ст. 12 КПК України, ніхто не може триматися під вартою, бути затриманим або обмеженим у здійсненні права на вільне пересування в інший спосіб через підозру або обвинувачення у вчиненні кримінального правопорушення інакше як на підставах та в порядку, передбачених КПК України. Отже, маючи чітку законодавчу вимогу щодо визначення порядку затримання та тримання під вартою лише КПК України, маємо ситуацію, коли законодавець передбачив такий вид затримання, який у кодексі не передбачено. 3 цього приводу експерти Харківської правозахисної групи вказують, що розробники закону здійснили спробу запровадити позасистемний інститут «превентивного затримання», що символізує появу на додаток до кримінального процесуального права нової галузі, яку умовно можна назвати «кримінальним екстрапроцедурним правом», що є неприпустимим [3]. Отже, на сьогодні маємо картину «відірваності» превентивного затримання від норм КПК України, що призводить до неурегульованості багатьох питань. Перша і основна проблема, що виникає з приводу регламентації превентивного затримання, це взагалі законність його здійснення.

Принагідно слід звернути увагу на положення ст. 615 КПК України (якими регламентовано особливий режим досудового розслідування в умовах воєнного, надзвичайного стану або у районі проведення антитерористичної операції), де визначена можливість тримання під вартою на строк до 30 діб. Отже, якщо у ст. 15-1 Закону України «Про боротьбу з тероризмом» йдеться про превентивне затримання, то у ст. 615 КПК України - про тримання під вартою. Відтак, є незрозумілим, чому в цих положеннях законодавець веде мову про один захід, допустивши різне термінологічне його визначення, чи про різні заходи?

Для з'ясування сутності превентивного затримання необхідно встановити, що ж є підставою його здійснення. Зі змісту ст. 615 КПК України стає зрозуміло, що особливий режим досудового розслідування здійснюється лише при розслідуванні злочинів, передбачених ст. 109-114-1, 258-258-5, 260-263-11, 294, 348, 349, 377-379, 437-444 КК України. Відтак, можемо зрозуміти, що підставою тримання під вартою на строк до 30 діб (або превентивного затримання, якщо вважати, що законодавець порівнює ці заходи) є наявність обгрунтованої підозри у вчиненні особою терористичної діяльності, у тому числі вчинення кримінального правопорушення, передбаченого статтями 109-114-1, 258-258-5, 260-263-1, 294, 348, 349 , 377-379, 437-444 Кк України.

Слід звернути увагу й на той факт, що ані Законом України «Про боротьбу з тероризмом», ані в КПК України не визначено порядку фіксації превентивного затримання. Зокрема, у п. 2.2. Інструкції про порядок превентивного затримання визначено, що про затримання особи уповноваженою службовою особою складається протокол у порядку, передбаченому ст. 208 КПК України. У п. 2.3 цього нормативного акту йдеться про те, що керівники уповноважених органів МBC або 
СБУ у разі отримання інформації, яка надійшла до чергової частини ГУ СБУ або ГУ МВС, зобов'язані невідкладно приступити до вирішення питання про превентивне затримання. Крім того, у діючій редакції ч. 4 ст. 15-1 Закону України «Про боротьбу з тероризмом» вказано, що превентивне затримання здійснюється за вмотивованим рішенням начальника ГУ СБУ або начальника територіального органу НП. У п. 2.10 вказаної Інструкції передбачено, що перед вирішенням питання про надання згоди на превентивне затримання прокурором із дотриманням порядку, передбаченого ст. 214 КПК України, вносяться відповідні відомості до ЄРДР. Відтак, можна стверджувати, що рішення про превентивне затримання є колегіальним, в ньому беруть участь такі посадові особи: 1) уповноважені службові особи (якими можуть бути співробітники органів та підрозділів, які беруть участь у проведенні антитерористичної операції); 2) начальник ГУ СБУ або начальник територіального органу НП; 3) прокурор обласного рівня або його заступник у районі проведення антитерористичної операції.

Така регламентація зумовлює постановку наступного питання: чи може уповноважена службова особа скласти протокол про превентивне затримання (як того вимагає Інструкція), якщо необхідно погодження їі керівника і надання згоди прокурора? Зрозуміло, що ні, оскільки без погодження керівника СБУ або НП і без надання згоди прокурором протокол превентивного затримання не може бути складений. Втім, таке врегулювання порядку оформлення превентивного затримання свідчить про порушення логічної побудови самого процесу затримання, оскільки в Інструкції йдеться про розмежування факту затримання та надання згоди на превентивне затримання в межах кримінального провадження.

Крім того, в автора постає ще одне дискусійне питання: чи потрібно прокурору складати постанову про надання згоди на превентивне затримання? Ані КПК України, ані Закон України «Про боротьбу з тероризмом», ані Інструкція про превентивне затримання відповіді на це питання не дають. У п. 2.14 вказаної Інструкції передбачено обов'язок прокурора винести постанову про відсутність підстав для надання згоди на превентивне затримання. Втім, передбачивши обов'язок прокурора оформити своє рішення у формі постанови лише у разі незгоди з рішенням про превентивне затримання, законодавець «забув» передбачити процесуальну форму надання згоди на такий вид затримання.

Втім, у самому Законі України «Про боротьбу з тероризмом» вказується, що рішення про превентивне затримання приймає начальник ГУ СБУ або начальник територіального органу НП, а не прокурор. Відтак, зовсім не зрозуміло, яке ж рішення повинен прийняти прокурор / начальник ГУ СБУ, начальник територіального органу НП у разі надання згоди на превентивне затримання особи або прийняття рішення про його застосування? Оформити окремим рішенням (постановою) або затвердити протокол?

Отже, слід констатувати суперечливість усіх положень, що якимось чином регламентують порядок здійснення превентивного затримання: ст. 15-1 Закону України «Про боротьбу з тероризмом» не узгоджено із положеннями КПК України, а Інструкцією про превентивне затримання передбачено інший порядок здійснення цього заходу, ніж того вимагає Закон. 
Принагідно варто звернути увагу й на той факт, що пунктом 2.16. вищезгаданої Інструкції дозволяється затриманій особі у будь-який час оскаржити в суді своє затримання. Втім, з цього приводу у науковій літературі слушно вказується, що оскільки КПК, як основний документ, який регулює досудове розслідування в рамках кримінального провадження, не містить ані запобіжного заходу, ані процесуального рішення прокурора, можна справедливо стверджувати, що у разі оскарження такого рішення слідчий суддя скасує постанову про превентивне затримання [4, с. 266].

Отже, за таких суперечливих нормативних підходів однозначно слід стверджувати про необхідність внесення законодавчих змін: по-перше, щодо регламентації порядку здійснення превентивного затримання у КПК України; по-друге, щодо узгодження положень ст. 15-1 Закону України «Про боротьбу з тероризмом» із положеннями КПК України (зокрема, зі ст. 615 та з іншими статтями, що регламентують порядок застосування запобіжних заходів), а також із Інструкцією про порядок проведення превентивного затримання.

Наступним проблемним моментом, на якому хоче зупинити увагу автор, є строк превентивного затримання. Згідно ст. 14 Закону України «Про боротьбу 3 тероризмом» превентивне затримання осіб, причетних до терористичної діяльності, може здійснюватися на строк понад 72 години, але не більше ніж на 30 діб. Крім того, згідно п. 2.9 Інструкції про порядок превентивного затримання, загальний строк вирішення питання про превентивне затримання не може перевищувати 72 години з моменту фактичного затримання особи. У цей строк включається строк доставки затриманої особи до прокурора [2]. Отже, фактично у цій Інструкції розмежовується строк: 72 години для доставки особи до прокурора, 30 діб - максимальний строк превентивного затримання, після сплину якого особу повинно бути звільнено або обрано судом запобіжний заході у вигляді тримання під вартою. 3 огляду на значний правообмежувальний строк, можна сказати, що превентивне затримання є не стільки копією «процесуального» затримання, скільки аналогом такого запобіжного заходу, як тримання під вартою.

Автор зауважує, що закріплення строку превентивного затримання (30 діб) прямо суперечить конституційним положенням, якими визначено максимальний строк для затримання - 72 години (ст. 29 Основного Закону України). На очевидну суперечність законодавчих положень про строк превентивного затримання положенням ст. 29 Конституції України вказувалось й у висновку Головного науково-експертного управління на проект Закону України «Про внесення змін до Закону України «Про боротьбу з тероризмом» [5]. Слід констатувати, що превентивне затримання особи на термін до 30 діб фактично є триманням під вартою, і тому на нього повинні повністю поширюватися вимоги та гарантії, передбачені ст. 29 КонституціїУкраїни.

3 цього приводу, експерти Центру політико-правових реформ вказують, що немає практичної потреби у подібному режимі обмеження прав людини. Адже навіть якщо суди у зоні АТО не функціонують належним чином, то у правоохоронців завжди є можливість за 72 години вивезти затриману особу до суду, що знаходиться у сусідніх областях, районах та тим самим забезпечити дотримання гарантій, встановлених для неї Конституцією та КПК України [6]. 
Ще одним аспектом, якому слід приділити увагу, є суб’єкт прийняття рішення про превентивне затримання. Згідно ч. 4 ст. 15-1 Закону України «Про боротьбу з тероризмом» превентивне затримання здійснюється за вмотивованим рішенням начальника ГУ СБУ або начальника територіального органу НП за згодою прокурора та без ухвали слідчого судді, суду. Втім, згідно ст. 615 КПК України рішення про тримання під вартою особи, яка підозрюється у вчиненні терористичної діяльності, приймається прокурором. Отже, за таких законодавчих суперечностей так і не зрозуміло - хто приймає рішення про затримання особи на 30 діб: уповноважена службова особа, яка здійснила затримання, прокурор або начальник ГУ СБУ / начальник територіального органу НП? Ясно одне - це не слідчий суддя.

Законодавчі положення стосовно суб'єкта прийняття рішення про превентивне затримання не відповідають конституційним вимогам, згідно яких ніхто не може бути заарештований або триматися під вартою інакше як за вмотивованим рішеннял суду. Отже, в основному Законі України не встановлено жодного виключення з цього правила. Відтак, тримання особи під вартою за вчинення кримінального правопорушення може відбуватись лише за рішенням слідчого судді, суду, проте ніяк не за рішенням керівника правоохоронного органу чи прокурора. Аналогічні положення встановлено й міжнародними правовими актами.

Стаття 5 Конвенції про захист прав людини та основоположних свобод передбачає, що кожен, кого заарештовано або затримано, має негайно постати перед суддею чи іншою посадовою особою, якій закон надає право здійснювати судову владу. Отже, ані прокурор, ані працівник правоохоронного органу чи його керівник не мають таких повноважень. Крім того, немає жодних можливих винятків із правила про негайне доставлення затриманої особи до суду ні в національному законодавстві, ні в міжнародних договорах, ратифікованих Україною. Втім, на сьогодні, всупереч конституційним та міжнародним положенням, окремим представникам правоохоронних органів надано право протягом 30 діб тримати людину під вартою без судового рішення.

Слід сказати, що реалізація зазначених положень, крім порушень права особи на свободу та особисту недоторканність, може призвести також і до звернень до ЄСПЛ з вимогою стягнути з Державного бюджету України на користь особи шкоду, заподіяну їй незаконним триманням під вартою. У зв'язку з цим у науковій літературі, зокрема О.В. Капліною, А.Г. Катковою, вже зверталась увага на необхідність удосконалення порядку досудового розслідування в умовах воєнного, надзвичайного стану або в районі проведення антитерористичної операції [7, с. 50; 8, с. 221].

Висновки. Проведене дослідження засвідчило той факт, що порядок превентивного затримання потребує перегляду на законодавчому рівні. Системний аналіз положень КПК України та Закону України «Про боротьбу з тероризмом» засвідчив факт їх неузгодженості та суперечності. Крім того, закріплення превентивного затримання викликає сумнів у законності його регламентації та зумовлює питання щодо відповідності законодавчих положень про строки та порядок його здійснення Конституцією України. Порядок такого виду затримання на законодавчому рівні фактично не визначено, а підзаконне врегулювання цього інституту є недосконалим. 
За таких обставин є два шляхи виходу. Перший - це виключення законодавчих положень про превентивне затримання як таких, що суперечать Конституції України в частині строків, порядку їх здійснення. Другий - приведення у відповідність положень ст. 15-1 Закону України «Про боротьбу з тероризмом» положенням Конституції України та КПК України. На думку автора цієї роботи, в умовах здійснення воєнних дій на сході України та проведення антитерористичної операції, доцільно йти другим шляхом. Разом з цим, такий шлях можливий лише за умови визначення в КПК України превентивного затримання видом запобіжних заходів; визначення підстав такого затримання; регламентації порядку його здійснення із вказівкою на суб'єктів безпосереднього затримання та суб'єктів подальшого прийняття рішення про тримання під вартою в межах кримінального провадження. Також потребують узгодження положення про строки превентивного затримання та суб'єктів, які приймають рішення про тримання під вартою на строк понад 72 години, зі ст. 29 Конституцією України. Лише у цьому випадку не буде підстав називати превентивне затримання «позапроцесуальним заходом» .

\section{Jimepamypa}

1. Про боротьбу з тероризмом: Закон України від 20.03.2003 p. № 638-IV. URL: https://zakon. rada.gov.ua/laws/show/638-15.

2. Про затвердження Інструкції про порядок превентивного затримання у районі проведення антитерористичної операції осіб, причетних до терористичної діяльності, та особливого режиму досудового розслідування в умовах воєнного, надзвичайного стану або у районі проведення антитерористичної операції: Наказ MBC України, ГП України, СБУ України 26.08.2014 № 872/88/537 URL: https://zakon.rada.gov.ua/laws/show/z1038-14.

3. Усенко I., Ромінський Є. Превентивне затримання v. 2.0: недомислення чи рецидив репресивної ментальності? Закон і бізнес. 6.05.2014. URL: http://zib.com.ua/ua/print/83968-preventivne_ zatrimannya_v20_nedomislennya_chi_recidiv_repres.html.

4. Сироткіна А.О. Превентивне затримання неповнолітнього. Право і суспільство. 2018. № 4. Частина 2. С. 264-268.

5. Висновок на проект Закону України «Про внесення змін до Закону України «Про боротьбу з тероризмом» щодо превентивного затримання у районі проведення антитерористичної операції осіб, причетних до терористичної діяльності, на строк понад ніж 72 години»: Висновок Головного науково-експертного управління на проект Закону № 4312a від 21.07.2014 p. URL: http://w1.c1.rada.gov.ua/pls/zweb2/webproc34?id=\&pf3511=51738\&pf35401=309582.

6. Малишев Б., Банчук О. Про «диктаторські» закони демократичної держави. Сайт Центру політико-правових реформ. 17.09.2014.URL:http://pravo.org.ua/2011-07-05-15-26-55/2011-07-22-11-18-16/ 1749-pro-dyktatorski-zakony-demokratychnoi-derzhavy.html.

7. Капліна О.В. Проблеми застосування норм кримінального процесуального законодавства в умовах проведення АТО: Досудове розслідування: актуальні проблеми та шляхи їх вирішення : матеріали пост. діючого наук.-практ. семінару, 17 жовт. 2014 р. Харків, 2014. Вип. 6. С. 46-51.

8. Каткова А.Г. Деякі питання здійснення досудового розслідування в умовах воєнного, надзвичайного стану та у районі проведення антитерористичної операції. Науковий вісник Дніпропетровського державного університету внутрішніх справ. 2016. № 2. С. 216-223. 


\begin{abstract}
Анотація
Фоміна Т. Г. Превентивне затримання: запобіжний або «позапроцесуальний» захід? - Стаття.

Поява у 2014 році в національному законодавстві превентивного затримання спричинила серед правників суперечки щодо доцільності його існування. У статті визначено сучасні проблеми регламентації порядку превентивного затримання; окреслено проблемні моменти щодо визначення строків превентивного затримання та суб'єктів його здійснення; з'ясовано відмінності між превентивним затриманням та затриманням у порядку ст. 208 КПК України, а також триманням під вартою; висловлено власний погляд щодо можливого вдосконалення законодавства в частині регламентації порядку превентивного затримання.

Зроблено висновок, що порядок превентивного затримання потребує перегляду на законодавчому рівні. Системний аналіз положень КПК України та Закону України «Про боротьбу з тероризмом» засвідчив факт їхньої неузгодженості та суперечності. Крім того, закріплення превентивного затримання викликає сумнів у законності його регламентації та зумовлює питання щодо відповідності законодавчих положень про строки та порядок його здійснення Конституції України. Порядок такого виду затримання на законодавчому рівні фактично не визначено, а підзаконне врегулювання цього інституту є недосконалим.

Автором висловлено переконання, що в умовах здійснення воєнних дій на Сході України та проведення антитерористичної операції положення ст. 15-1 Закону України «Про боротьбу з тероризмом» доцільно привести у відповідність до положень Конституції України та КПК України. Такий шлях можливий лише за умови визначення в КПК України превентивного затримання видом запобіжних заходів; визначення підстав такого затримання; регламентації порядку його здійснення із вказівкою на суб'єктів безпосереднього затримання та суб'єктів подальшого прийняття рішення про тримання під вартою в межах кримінального провадження. Також потребують узгодження положення про строки превентивного затримання та суб'єктів, які приймають рішення про тримання під вартою на строк понад 72 години, зі ст. 29 Конституцією України.

Ключові слова: запобіжний захід, превентивне затримання, тримання під вартою, затримання, прокурор, проведення АТО.
\end{abstract}

\title{
Summary
}

Fomina T. H. Preventive detention: is it preventive or "non-procedural" measure? - Article.

Introduction of preventive detention in national legislation in 2014 has caused controversy among lawyers about the expediency of its existence. The author of the article has defined the current problems in the regulation of preventive detention's procedure; has outlined the problematic issues on determining the terms of preventive detention and the subjects of its implementation; has clarified the differences between preventive detention and detention within the Art. 208 of the Criminal Procedural Code of Ukraine, as well as detention in custody; has expressed own opinion on the possible improvement of the legislation regarding the regulation of preventive detention's procedure.

It has been concluded that preventive detention's procedure requires to be reviewed at the legislative level. The systematic analysis of the provisions of the Criminal Procedural Code of Ukraine and the Law of Ukraine "On Combating Terrorism" demonstrated the fact of their inconsistency and contradiction. Besides, consolidation of preventive detention raises doubts about the legality of its regulation and raises questions about the conformity of the legislative provisions on terms and the procedure for its implementation to the Constitution of Ukraine.

The procedure for this type of detention at the legislative level is virtually undefined, and substatutory regulation of this institution is imperfect. The author has expressed her conviction that it is expedient to align the provisions of the Art. 15-1 of the Law of Ukraine "On Combating Terrorism" with the provisions of the Constitution of Ukraine and the Criminal Procedural Code of Ukraine in the conditions of hostilities in the East of Ukraine and conduction of anti-terrorist operation.

Such a way is possible only if the Criminal Procedural Code of Ukraine determines preventive detention as the type of preventive measures; determining the reasons for such detention; regulation of the procedure for its implementation, with reference to the subjects of direct detention and the subjects of subsequent decision-making on detention in custody within criminal proceedings. Provisions on the terms of preventive detention and the subjects who make decisions on detention in custody for more than 72 hours also need to comply with the Art. 29 of the Constitution of Ukraine.

Key words: preventive measure, preventive detention, custody, detention, prosecutor, conduction of anti-terrorist operation. 